\title{
Singularidade e formação (Bildung) em Schopenhauer como educador de Nietzsche*
}

José Fernandes Weber

Universidade Estadual de Londrina

Correspondência:

José Fernandes Weber

Rua Paranaguá, 803, apto 54

86020-030 - Londrina - PR

e-mail: jweber@uel.br

\section{Resumo}

A partir do escrito Schopenhauer como educador, buscar-se-á explicitar a dimensão modelar de Schopenhauer, tanto para a constituição do ideal de filósofo e pensador que Nietzsche cria para si, quanto para a edificação da sua teoria da formação (Bildung). Isso será dado, num primeiro momento, pela apresentação do pendor crítico do pensamento schopenhaueriano e da sua insubmissão às tendências filosóficas e culturais do seu tempo; num segundo momento, pela elucidação da especificidade da teoria nietzschiana do autoconhecimento e da sua concepção da singularidade, com o que se revelará sua teoria do fundamento metafísico da natureza, que o leva a conceber o filósofo, o artista e o santo como os tipos singulares por excelência nos quais a natureza justifica os seus esforços e supera a mera necessidade. Essas tipologias revelam as tarefas que a educação deve, ao juízo de Nietzsche, perseguir se não quiser se tornar mero abstracionismo ou mera aderência acrítica ao mundo: jamais condescender aos modismos culturais; não separar pensamento e vida com o que se diz, também, que teoria e prática não estão separadas; incorporar a singularidade como aquilo que a educação promove; e, por fim, eleger a autossuperação como a tarefa mais imperiosa para a constituição do humano no seu sentido mais pleno.

\section{Palavras-chave}

Singularidade - Formação (Bildung) - Schopenhauer - Nietzsche.

\footnotetext{
* Este artigo resulta da pesquisa desenvolvida no Projeto de Pesquisa "Bildung (Formação, Cultivo) e Modernidade: entre Filosofia, Educação e Artes" (n. 9051), financiado pela Fundação Araucária - Paraná (FAP) e também do "Estágio de Doutorando no Exterior" (SWE), concedida pela CAPES, realizado entre maio de $2004 \mathrm{e}$ fevereiro de 2005 na Universidade Nova de Lisboa (UNL) sob orientação do Prof. Dr. António Marques.
} 


\title{
Singularity and formation (Bildung) in Schopenhauer as educator of Nietzsche*
}

\author{
José Fernandes Weber \\ Universidade Estadual de Londrina
}

Contact:

José Fernandes Weber

Rua Paranaguá, 803, apto 54

86020-030 - Londrina - PR

e-mail:jweber@uel.br
*This article resulted from the study developed within the Research Project "Bildung (Formação, Cultivo) e Modernidade: entre Filosofia, Educação e Artes" [Bildung (Formation, Cultivation) and Modernity: between Philosophy, Education, and Arts] (n. 9051) sponsored by Fundação Araucária - Paraná (FAP) and also by the "Doctorate Sojourn Abroad" (SWE) granted by CAPES during the period of May 2004 and February 2005 at the Universidade Nova de Lisboa (UNL) under the supervision of Professor António Marques.

\begin{abstract}
Based on Nietzsche's Schopenhauer as Educator, the text seeks to unveil Schopenhauer's model dimension both in the constitution of the ideal of philosopher and thinker that Nietzsche creates to himself, and in the construction of his theory of formation (Bildung). The objective of the article is pursued firstly through the presentation of the critical disposition of the Schopenhauerian thinking and of his refusal to conform to the philosophical and cultural tendencies of his time; then, in a second movement, the text elucidates the specificity of the Nietzschean theory of self-knowledge, and of his concept of singularity, which reveal his theory of the metaphysical ground of nature, leading him to envision the philosopher, the artist, and the saint as the singular types par excellence, in which nature justifies her efforts and goes beyond mere necessity. These typologies reveal the tasks that education, in Nietzsche's view, must engage in if it is to avoid becoming mere abstractionism or noncritical acceptance of the world: to never condescend to cultural fashions; not to separate thinking and life, meaning also that theory and practice go together; to incorporate singularity as that which education promotes; and, lastly, to elect going beyond oneself as the most imperative task in the constitution of the human being in its fullest sense.
\end{abstract}

\section{Keywords}

Singularity - Formation (Bildung) - Schopenhauer - Nietzsche. 
Supondo que os seres humanos sejam singulares, não seria fazer pouco da singularidade humana pretender que sua formação estivesse balizada pelo princípio do desenvolvimento médio das suas faculdades? Não é justamente esse o princípio das instituições educativas, dos estabelecimentos de ensino? A padronização do ritmo do ensino tende inevitavelmente a isso. No entanto, considerando as possibilidades do ensino institucionalizado, não seria a padronização uma característica benéfica? Afinal, ao garantir a um número maior de pessoas o acesso aos rudimentos básicos, ela deixa o espaço para a diferenciação ser decidida pelo imponderável, pelas aglomerações casuais, pela constituição individual, pelo gênio de cada um. Ou seja, como o singular não ocorre por si só, independentemente do mundo, a padronização dos estabelecimentos de ensino não negaria necessariamente a singularidade, realçando-a, por contraste, quando ela eclode.

A oposição entre o individual e o coletivo, entre o singular e o padronizado, é uma das polaridades mais características da modernidade. Da teoria política, passando pelas teorias morais e epistemológicas, até a inserção nas discussões estéticas, essa polaridade marcou também, e continua marcando, os discursos sobre a formação. Os textos Sobre o futuro dos nossos estabelecimentos de ensino ${ }^{1}$ e Schopenhauer como educador, de Friedrich Nietzsche, representam dois momentos privilegiados, tanto para a análise daquela contraposição no plano mais específico da formação filosófica, quanto da instauração de um movimento de fuga por meio do qual se mostra a impossibilidade de interpretar o singular como sinônimo de individual, pura e simplesmente. 0 singular é muito mais do que o individual. Os tipos pedagógicos do artista, do santo e do filósofo, apresentados por Nietzsche em Schopenhauer como educador, permitem explicitar a distinção entre o singular e o individual, com o que se põe em evidência a raiz metafísica da teoria nietzschiana do gênio filosófico, elemento decisivo da sua teoria da formação da singularidade, o também chamado unicum. A referência ao tema da decadência dos estabelecimentos de ensino e da cultura alemã - objeto específico de discussão das conferências sobre os estabelecimentos de ensino alemães - permite identificar um melancólico e renitente eco, quase inaudível da outrora sonora Grécia, que também se tornou decadente, tal qual a Alemanha contemporânea de Nietzsche. Entretanto, será que os alemães jamais abandonarão o sonho de reconquistar o "autêntico espírito grego"? Todavia, após o abandono do projeto de renascimento do espírito trágico na Alemanha sonho acalentado em sua primeira grande obra, $O$ nascimento da tragédia -, quem faz Nietzsche almejar um modelo de formação superior já não são mais os gregos, e sim o velho solitário de Frankfurt: Arthur Schopenhauer.

Assim, tendo como referência o escrito Schopenhauer como educador, buscar-se-á explicitar a dimensão modelar de Schopenhauer, tanto para a constituição do ideal de filósofo e pensador que Nietzsche cria para si, quanto para a edificação da sua teoria da formação (Bildung). Isso será dado, num primeiro momento, pela apresentação do pendor crítico do pensamento schopenhaueriano e da sua insubmissão às tendências filosóficas e culturais do seu tempo; num segundo momento, pela elucidação da especificidade da teoria nietzschiana do conhecimento, do autoconhecimento e da sua concepção da singularidade, com o que se revelará sua teoria do fundamento metafísico da natureza, que o leva a conceber o filósofo, o artista e o santo como os tipos singulares por excelência nos quais a natureza justifica os seus esforços e supera a mera necessidade.

\section{O que nos ensinaria um mestre que não aprenderíamos por nós próprios?}

Um mestre é absolutamente indispensável? Em que sentido um mestre é fundamental?

1. Texto das cinco conferências proferidas por Nietzsche na Universidade de Basileia em 1872, em que o autor critica as tendências da educação alemã do seu tempo, fazendo uma ampla reflexão sobre o significado, as peculiaridades e a importância da educação (Erziehung) e da formação (Bildung). A esse respeito, ver WEBER, 2008. 
Se as conferências acerca dos estabelecimentos de ensino alemães são enfáticas em realçar a imagem de uma instituição exigente, pautada nos princípios da autoridade e da obediência, em Schopenhauer como educador, essa imagem será aprofundada por meio da apresentação da experiência com um mestre a tal ponto exigente que se torna desarticulador, responsável por uma profunda crise que levará o indivíduo a assumir a tarefa da autoformação. Para Nietzsche, encontrar a obra de Schopenhauer representou um acontecimento após o qual o fundamental encontrava-se, senão transformado, pelo menos em crise. Aqui cabe mostrar a importância do homem-filósofo Schopenhauer no "devir filósofo" de Nietzsche, mais do que apresentar e discutir as teses da filosofia schopenhaueriana. Ele será um exemplo incontornável para Nietzsche, não tanto pela sua filosofia, pelas suas ideias - em relação às quais este, desde o início, manteve uma posição de aceitação, e também de recusa, de crítica -, mas pela forma peculiar de tornar-se e manter-se filósofo à margem da filosofia oficial do Estado prussiano e à margem da indiferença e do silêncio dos seus contemporâneos. Além disso, o texto sobre Schopenhauer permite esclarecer algumas das teses das conferências sobre os estabelecimentos de ensino, aprofundadas pela apresentação e pelo desenvolvimento da tese do fundamento metafísico da formação do gênio filosófico, bem como apontar para algumas mudanças significativas.

"Schopenhauer, um pessimista, educador? Isso já é demais”, diriam as boas almas educadas na religião ou no humanismo. Por qual razão agravar a gravidade da vida? 0 que se ganharia com o realce dos aspectos sombrios da existência? Absolutamente nada. E seria necessário insistir no fato de que o tão malfalado pessimismo schopenhaueriano não se reduz a uma descrição literal das atrocidades do mundo. Fosse isso, não seria filosofia, seria, no máximo, jornal da manhã ou diário popular. Além do que, Nietzsche o mostrará em sua imagem do mestre, não é o seu pessimismo que educa, e sim sua dureza e fortaleza.
Mais do que seu pensamento, o que educa é o homem-filósofo Schopenhauer. Essa ideia ou noção é decisiva para a compreensão da teoria nietzschiana da formação do gênio no período posterior a $O$ nascimento da tragédia e anterior a Humano, demasiado humano. No entanto, não seria exato concluir que a filosofia schopenhaueriana não tenha exercido influência nesse momento de seu pensamento. Normalmente se restringe a influência do pensamento de Schopenhauer sobre Nietzsche à sua primeira obra, NT. Entretanto, em Schopenhauer como educador, é possível verificar que a influência persiste, apesar de todo o movimento de crítica e recusa de alguns dos princípios da filosofia schopenhaueriana, movimento crítico facilmente verificável nos escritos relativos ao período e que foram publicados postumamente por ocasião da edição completa das obras de Nietzsche. A referência ao tema da propensão metafísica da natureza, central em Schopenhauer como educador, é um tema schopenhaueriano, assim como a referência ao filósofo, ao artista e ao santo como aqueles que justificam a natureza. Embora o tema da superioridade do gênio criador seja romântico, a maneira como Nietzsche o emprega segue a interpretação schopenhaueriana. Em suma, o fato de ele valorizar sobremaneira o devir-filósofo de Schopenhauer, não significa que este, com suas teorias, tenha sido completamente preterido. Isso apenas acontecerá alguns anos mais tarde.

Schopenhauer ocupará uma posição de destaque, juntamente com Wagner, num projeto que Nietzsche desenvolveu naquele período. Imediatamente após a publicação de $O$ nascimento da tragédia, Nietzsche concebeu um projeto de crítica da cultura alemã, denominado de Considerações Extemporâneas (CE). Embora projetasse inicialmente um número bastante grande de escritos, restringiu-se à publicação de quatro ensaios: David Strauss, o crente e o escritor (1), Dos benefícios e das desvantagens da história para a vida (11), Schopenhauer como educador (111) e Richard Wagner em Bayreuth (IV). A extemporaneidade das quatro Considerações - 
e quiçá de todo o pensamento nietzschiano repousa na luta "contra o seu tempo". Referindo-se a CE I1, e por extensão a todas as outras, Nietzsche assim se expressou: "Se esta consideração é extemporânea, é porque eu considero como um mal, como uma deficiência, como uma carência, uma coisa que o tempo presente glorifica, a sua cultura histórica" (Prefácio). Submeter a uma crítica radical os objetos de orgulho e autossatisfação, do amor próprio da cultura alemã: esse era o objetivo das Extemporâneas. Daí o tom de disputa, crítica e ironia empregada nesses textos. Aliás, nesse sentido, não seria despropositado dizer que as conferências de Basileia representam um primeiro esboço das Extemporâneas. Assim, o texto sobre Schopenhauer representará o contraponto mais radical à autossatisfação dos alemães, um contraponto, porém, não meramente negativo, pois, insiste Nietzsche, Schopenhauer educa.

Essa convicção é expressa ao longo de todo o texto em que Schopenhauer é caracterizado como sendo um pessimista afirmativo ${ }^{2}$. E, embora possa parecer estranho, a imagem deste, em Schopenhauer como educador, é a de um tipo afirmativo, que legisla não apenas sobre a sua vida, mas também sobre o seu pensamento, enfrentando a tudo e a todos. Além disso, como indivíduo, ele se mantém numa atitude de fortaleza a despeito do mundo e dos perigos que acometem a cada homem. No caso do gênio, contudo, a realidade assola-o de forma mais violenta. A solidão, o desespero da verdade e a nostalgia foram os perigos aos quais Schopenhauer esteve exposto, mas aos quais não sucumbiu.

A crer na caracterização de Nietzsche, Schopenhauer foi um solitário que sacrificou a promessa de felicidade coletiva para salvaguardar a integridade da sua filosofia e do seu ser. 0 filósofo solitário não deixou abater sobre si a maldição segundo a qual "há sempre, em toda solidão, uma culpa secreta" (Nietzsche, 2004, p. 153). Não se sentia culpado e via na solidão a única forma de vida compatível com o espírito filosófico.
Além disso, o desespero da verdade afetou-o como a todos os que foram tocados profundamente pela filosofia kantiana. Contudo, não cedeu ao ceticismo. A crítica, tanto do realismo escolástico quanto do essencialismo, do racionalismo e do empirismo, levou, ao menos em uma interpretação bastante peculiar na Alemanha, a uma espécie radical de ceticismo em que o suicídio parecia ser uma alternativa viável. Esse foi o famoso caso de Kleist que, em uma carta à irmã, dizia ter sido jogado em uma profunda crise após a leitura da Crítica da razão pura. E, embora este tenha cometido suicídio por não suportar continuar vivendo num mundo do qual foram solapadas as certezas - consequência, ao juízo dele, da crítica kantiana, juízo e ato endossado por muitos outros -, Schopenhauer encontra na filosofia de Kant um pensamento que, a despeito da dificuldade e da força de pensamento que exige do leitor, dá na mesma medida em que exige e com a mesma força e proporção. Nietzsche (2004) faz aqui uma nova interpretação curiosa: diz que o pensamento kantiano fecunda apenas a homens robustos, que são completos "no sofrimento e no desejo, e não simples máquinas de pensar" (p. 155). Quer dizer, aquilo que levaria outros ao fundo fortaleceu a Schopenhauer. Por quê? Porque ele era um homem robusto, não um erudito ou um artista delicado.

Por fim, na nostalgia, ele teve o seu adversário mais forte, mais difícil de ser superado, pois, como pensa Nietzsche (2004), a sua constituição o dispunha para tal.

Todo homem encontra normalmente em si um limite dos seus dons, assim como do seu querer moral, e este limite o enche de nostal-

2. Um amplo campo de investigação poderia ser aberto caso se relacionasse o juízo, contido em Schopenhauer como educador, sobre Schopenhauer como sendo o de um tipo afirmativo, com os temas do Amor Fati e da Vontade de Poder, característicos de sua filosofia tardia. Isso entretanto, exigiria o tratamento de um conjunto de temas e problemas cujo desenvolvimento não pode ser incorporado ao presente artigo, pois remete, inclusive, a questões que não possuem relação alguma com os objetivos aqui propostos. 
gia e melancolia [...]. Ora, a natureza de Schopenhauer envolvia uma dualidade estranha e extremamente perigosa [...]. Assim, ele sabia que tinha uma parte do seu ser satisfeita e cumprida, sem desejo, certa da força que possuía - assim, consciente de ser uma realização vencedora, carregava sua vocação com grandeza e dignidade. Uma nostalgia impetuosa vivia na outra metade do seu ser. Compreendemos isto ao ouvi-lo dizer que ele se afastava com um olhar pesaroso de um retrato de Rancé, o grande fundador da Ordem dos Trapistas, murmurando estas palavras: 'Eis aí a obra da Graça'. Pois o gênio aspira cada vez mais a santidade que, a partir do seu posto de observação, ele viu mais longe e mais claro do que qualquer outro homem, lá onde o conhecimento e o ser se reconciliam, lá onde dominam a paz e a negação do querer, e até esta outra margem da qual falam os hindus. (p. 158-159)

A despeito dessa tendência, Schopenhauer não sucumbiu à negação, atitude pela qual se torna exemplar: afinal, superar a força que o arrastava, a partir de si, para a negação, representou sua mais difícil tarefa. Com isso, ele permaneceu filósofo no sentido mais forte do termo, pois o movimento de negação passou a ocupar um lugar central em sua filosofia. Quer dizer, a negação, como princípio metafísico, tornou-se elemento central do seu pensamento filosófico. E tudo isso, pensa Nietzsche, de forma robusta, viril, sem concessões a uma atitude subjetiva lamuriante ou a um relativismo fraco.

Após mostrar como Schopenhauer se defendeu vigorosamente desses três perigos, vencendo-os, Nietzsche (2004) afirma:

Estes três perigos constitutivos que ameaçam Schopenhauer também nos ameaçam a todos [...]. Para a maioria das pessoas, há aí algo de insuportável, porque, como já disse, elas são preguiçosas e porque a esta unicidade se liga toda uma cadeia de tormentos e fardos. (p. 159)
Assim, chegamos ao estágio em que, após indicado brevemente os motivos pelos quais Schopenhauer é modelar, podemos apresentar as teses do texto de Nietzsche. Vamos apresentá-las em forma de tópicos para dar o destaque que merecem e realçar sua visibilidade:

1. Os seres humanos são naturalmente preguiçosos;

2. A natureza é aristocrática, e a cultura também deve sê-la;

3. A educação deve libertar ${ }^{3}$;

4. A cultura possui uma significação metafísica. Assim, deve-se, por meio dela, possibilitar a criação do filósofo, do artista e do santo, que são aqueles que justificam a natureza no seu perpétuo desperdício de seres. A cultura completa a natureza, pois ela vem em auxílio da physis e corrige suas loucuras (Nietzsche, 2004);

5. Cada ser humano é único.

\section{A tipologia pedagógica do Unicum: o filósofo, o artista e o santo}

Se o homem é único - "ein Unicum" (Nietzsche, 2004) -, se habita a consciência da sua singularidade, como explicar que algo como o rebanho seja possível, seja a regra, e a singularidade, exceção? Que o homem, a despeito da sua incontornável solidão, encontre no convívio com os outros um espaço para a constituição e a formação do seu si próprio, não deveria levá-lo a abdicar de si, se é que alguma vez tenha chegado a ser possuidor da presença de si. É inevitável que a imagem do humano oscile entre uma besta coletiva inconsciente e um solitário criminoso fugitivo? A pergunta que preside o texto sobre Schopenhauer e que tam-

3. A tese do caráter libertário da educação vincula o texto Schopenhauer como educador ao texto Sobre o futuro dos nossos estabelecimentos de ensino, em que a formação é caracterizada como aquilo que possibilita ao homem tomar sobre si o seu próprio destino, como o que cria ao homem o desejo pela insubmissão. Além disso, o texto sobre Schopenhauer também pode ser visto como uma primeira aparição, embora tímida e apenas insinuada, do tema do espírito livre, figura central nas reflexões de Nietzsche a partir de Humano, demasiado humano. A esse respeito, ver Weber, 2008. 
bém se insinua nas conferências de Basileia é: Por que é tão difícil ao homem manter-se na presença de si sem se evadir com a ajuda de algum narcótico para o corpo ou para a alma? Singularidade, autenticidade e honestidade são formas e modos de ser que dificilmente andarão juntos. Por quê? Schopenhauer como educador pretende responder a essas perguntas.

Ao ser perguntado que natureza encontrou nos homens em todos os lugares, o viajante que viu muitos países e povos e vários continentes respondeu: eles têm uma propensão à preguiça. Alguns acharão que ele teria respondido com mais justeza e razão: todos são timoratos. Eles se escondem atrás de costumes e opiniões. No fundo, todo homem sabe muito bem que não se vive no mundo senão uma vez, na condição de um único [als ein Unicum], e que nenhum acaso, por mais estranho que seja, combinará pela segunda vez uma multiplicidade tão diversa neste todo único que se é [Einerlei]: ele o sabe, mas esconde isso como se tivesse peso de consciência - por quê? Por medo do próximo que exige esta convenção e nela se oculta. Mas o que obriga o indivíduo a temer seu vizinho, a pensar e agir como animal de rebanho e a não se alegrar consigo próprio? Em alguns muito raros, talvez o pudor. Mas na maioria dos indivíduos, é a indolência, o comodismo, em suma, esta propensão à preguiça da qual falava o viajante. Ele tem razão: os homens são ainda mais preguiçosos do que timoratos e temem antes de mais nada os aborrecimentos que lhes seriam impostos por uma honestidade e uma nudez absolutas. (p. 138)

Poucos são os textos em que fica expresso, de maneira tão clara e contundente, o anti-iluminismo de Nietzsche. "O homem é preguiçoso" - mais tarde ele dirá: "0 homem é cruel”. Frente a essa constatação, todo o projeto iluminista parecerá uma ingênua carta de boas intenções cuja vigência sempre está por se concretizar, mas que nunca se efetiva. Todavia, essa atitude de cuidadosa reserva, se não de desconfiança, frente ao poder de emancipação da razão por meio do processo formativo do homem - independente da forma como é concebido -, não é algo novo. Ela pode ser surpreendida num dos textos mais esclarecedores sobre o significado do conhecimento e da educação para os iluministas, que é $A$ refutação de Helvetius, escrito de Denis Diderot (1994). Segundo esse autor, a teoria de Helvetius pode ser resumida na seguinte frase: "E educação tudo faz" (p. 841), ao que ele objeta: “A educação faz muito” (p. 841), mas não tudo. Quer dizer, apesar da existência de certo otimismo contido na crença iluminista acerca dos poderes do conhecimento e da educação - otimismo que faz Helvetius (1989) afirmar que a educação tudo faz; que leva locke (1986) a dizer que "[...] é possível afirmar que de todos os homens que encontramos nove décimos são o que são, bons ou maus, devido a educação que receberam" (p. 31); e que faz Kant (1995) declarar que "[...] é perfeitamente possível que um público a si mesmo se esclareça. Mais ainda, é quase inevitável, se para tal lhe for dada liberdade" (p. 12) -, também é possível identificar nos autores iluministas uma percepção clara a respeito dos limites e das dificuldades do esclarecimento. Diderot sabia quão poderosa era a ignorância, quão forte o obscurantismo. E Kant (1995), na mesma resposta a pergunta: o que é o esclarecimento?, após ter declarado que era quase inevitável que um povo se esclarecesse, desde que the fosse concedida a liberdade, afirma: "Por conseguinte, um público só muito lentamente pode chegar à ilustração" (p. 13).

Se é assim, a que se referiria a suposta ingenuidade iluminista, já que os próprios iluministas foram os primeiros a perceber as dificuldades para o esclarecimento? A grande diferença entre o iluminismo moderno e Nietzsche reside na concepção de natureza humana: para o filósofo, o homem é preguiçoso. Isso não quer dizer que o homem não seja laborioso, industrioso. Quem o negaria? Aliás, Hölderlin, autor de 
grande importância para Nietzsche, numa carta dirigida ao irmão Karl, datada de 4 de junho de 1799, torna célebre a imagem segundo a qual o labor e a transformação das condições da vida é uma pulsão humana fundamental. Diz Hölderlin (1994):

Por que eles não vivem como o selvagem na floresta, na suficiência, no limite do solo e da alimentação que se encontra imediatamente ao seu redor, numa coesão com a natureza tal como a criança no peito da mãe? Assim não haveria desassossego, fadiga, lamento, noites de insônia e somente pouca doença e pouca discórdia. Isso, no entanto, seria tão antinatural para o homem como é antinatural para o animal os artifícios que o homem ensina. Promover a vida, precipitar e aprimorar o movimento de plenificação da natureza, idealizar o que encontra diante de si, eis a pulsão que mais caracteriza e distingue o homem e de onde surgem todas as suas artes e ocupações, todos os seus erros e sofrimentos. Por que existem jardins e campos? Porque o homem queria algo melhor do que encontrou. Por que existe comércio, navegação, cidades, estados, em todo o seu turbilhão, em tudo o que possuem de bom e de ruim? Porque o homem queria algo melhor do que encontrou. Por que existe ciência, arte e religião? Porque o homem queria algo melhor do que encontrou. (p. 127-128)

Se o homem quer algo melhor do que aquilo que ele encontra, como, então, sustentar a tese de Schopenhauer, endossada por Nietzsche, da preguiça humana congênita frente ao incansável engenho humano?

Ocorre que, segundo Nietzsche, a engenhosidade é sintoma e resultado da evasão do homem de si. Por isso, o labor humano não atesta a busca humana pelo autoconhecimento, pela elucidação do que significa existir nesse momento preciso do tempo e do espaço, das implicações em possuir uma língua específica e ter uma herança cultural determinada. Se o homem constrói pontes, cria engenhosas máquinas a ponto de a tecnologia entrar em confronto com sua natureza ou em auxiliar no seu aperfeiçoamento, em suma, se o homem é laborioso em tudo o mais, quando, porém, o assunto é empenhar-se em responder a pergunta "Quem sou?", ele mostra a lei incontornável do seu ser: a preguiça. Portanto, afirmar que o início do texto sobre Schopenhauer possui uma tendência antiiluminista implica em apontar para uma matriz teórica em que o aperfeiçoamento intelectual e moral parece como algo, se não impossível, ao menos improvável.

Como atestar a razoabilidade desse argumento? Parece ser possível fazê-lo por meio da apresentação de duas séries de argumentos acessórios que afirmam: "a verdade possui uma função social, não epistemológica, ontológica, lógica ou moral" e "os homens são covardes". Sobre a verdade e a mentira no sentido extramoral, datado de 1873, é um escrito em que tais teses são apresentadas.

De onde provém a crença na verdade? Por que preferimos a verdade à mentira, se é que a preferimos? Para Nietzsche (1988):

A verdade aparece como uma necessidade social: é depois aplicada a tudo por uma metástase, mesmo quando não é necessária [...]. Com a sociedade nasce a necessidade da veracidade, senão o homem vive em eternos véus. A fundação de Estados suscita a veracidade. (p. 473)

A vida em sociedade exige a uniformização dos comportamentos e dos valores. Esse procedimento de uniformização social - sustentado na ideia de justiça, princípio norteador do direito - segue um procedimento análogo ao da formação da linguagem, a fixação arbitrária do não idêntico (Nietzsche, 1997). A linguagem, construída a partir da relação dos homens com as coisas, é totalmente metafórica:

Acreditamos saber algo das coisas mesmas, se falamos de árvores, cores, neve e flores, 
e, no entanto, não possuímos nada mais do que metáforas das coisas, que de nenhum modo correspondem às entidades de origem. (p. 219-220)

Tal insuficiência, além de atestar a impotência de nosso intelecto, por outro lado, atesta a indiferença das coisas em relação ao homem. Nesse abismo intransponivel entre as coisas, o mundo e o homem (este como conhecedor do mundo - "sujeito do conhecimento" - e na fissura irremediável aberta entre homem e mundo), Nietzsche inseriu a sua reflexão sobre a linguagem - esta como metáfora de entidades que não conhecemos - e sobre o homem em estado de sociedade.

Segundo ele, em consonância com Schopenhauer, por necessidade e tédio, o homem deseja viver em sociedade, em rebanho. Para tanto, acordou um pacto em que se utilizava de signos resultantes de um processo arbitrário de nomeação. Se a base de sustentação do pacto é esse conjunto de códigos arbitrariamente "arranjados", designações como Justiça, Verdade e Bem não passam de palavras que repousam no vazio, visto que não há sentido originário. 0 seu valor é criado obedecendo às "pressões" do instante. No momento de instituição da vida social, tornou-se necessário acordar o sentido de bem e de justiça, pois a sua manutenção dependia disso. Ou seja, aquilo que é denominado "verdade" é apenas o resultado de um processo arbitrário, decorrente das necessidades da manutenção da vida social.

Afinal, por que desejamos a verdade? E quando a desejamos, o que nela desejamos? Há um condicionamento pelo qual o homem preferiria a verdade à mentira, o que o tornaria um ser veraz por natureza? De acordo com Nietzsche (1997),

[...] os homens, nisso, não procuram tanto evitar serem enganados, quanto serem prejudicados pelo engano: o que odeiam, mesmo nesse nível, no fundo não é a ilusão, mas as consequências nocivas, hostis de certas espécies de ilusões. É também em um sentido restrito semelhante que o homem quer somente a verdade: deseja as consequências da verdade que são agradáveis e conservam a vida: diante do conhecimento puro e sem consequências ele é indiferente, diante das verdades talvez perniciosas e destrutivas ele tem disposição até mesmo hostil. (p. 218)

A determinação do grau de significação do conhecimento não está relacionada com a verdade em si, e sim com o prejuízo ou o ganho dela decorrentes. Essa é a razão pela qual o tema da covardia aparece associado à preguiça. Afinal, além da disposição natural para colocar-se ao abrigo das exigências que um empenho consigo próprio criaria, o homem, por vaidade ou por simples necessidade de sobrevivência, dificilmente pode prescindir do convívio com o outro. É por essa razão que tememos o vizinho, como sugerido por Nietzsche no início do texto sobre Schopenhauer. Indispor-se com o próximo, com a comunidade, poderia implicar na sua ruína social. Assim, tanto a força da coerção social sobre o indivíduo quanto a sua covardia, associados à sua preguiça, são fortes condicionantes, criadores de inautenticidade, também chamada por Nietzsche de falta de estilo. Robert Musil (1989), em seu livro $O$ homem sem qualidades, descreve a mescla de estilos desta maneira:

Para ser exato, as abóbadas de sustentação eram do século XVII, o parque e o andar superior pareciam do século XVIIl, as fachadas tinham sido renovadas e um pouco prejudicadas no século XIX; portanto o todo estava um tanto confuso, como em retratos fotografados uns por cima dos outros; mas acaba-se parando ali, infalivelmente, e dizendo: Ah! E quando aquela coisa alva, graciosa e bela estava de janelas abertas, avistavam-se as paredes de livros, nobres e silenciosas, da casa de um homem de cultura. (p. 11)

0 homem inautêntico, como Nietzsche o concebe, expressa uma situação de carência 
mais crônica do que aquele relatado por Musil, pois não possui sequer a força para aglomerar em torno de si ou em si a distinção que estilos alheios poderiam conferir. Que não seja peculiar o estilo da construção relatado por Musil (1989) não impede o suspiro de admiração dos que passam. Por quê? Porque os grandes estilos dos séculos XVII e XVIIl estavam lá representados. Ocorre que, diz ele, o século XIX é aquele que renova, mas que também prejudica a construção. Quer dizer, o século XIX, além de não possuir estilo próprio, também não possui o poder de bem aglomerar o que já existe. Em Nietzsche, Schopenhauer aparecerá como aquele que, em virtude da força da sua personalidade e do seu estilo, seja da escrita, seja da vida, representará um banho frio, revigorante, à confusão e à fraqueza do estilo jornalístico do seu tempo.

No entanto, apesar disso tudo, permanece em Nietzsche um iluminismo mitigado. Ele possui uma relação de proximidade, mas também de crítica, com o tema do autoconhecimento, matriz de tantos humanismos e práticas religiosas de interiorização e de penitência. Teria Nietzsche se descuidado, dado um passo em falso, permanecendo aquém inclusive do iluminismo moderno que ele tanto criticou? A não ser que autoconhecimento já não tenha mais nada a ver com as práticas seculares de auscultação da interioridade. Pergunta-se ele:

Mas como nos encontrar a nós mesmos? Como o homem pode se conhecer? Tratase de algo obscuro e velado; e se a lebre tem sete peles, o homem pode bem se despojar setenta vezes das sete peles, mas nem assim poderia dizer: "Ah! Por fim, eis o que tu és verdadeiramente, não há mais invólucro". É também uma empresa penosa e perigosa cavar assim em si mesmo e descer à força, pelo caminho mais curto, aos poços do próprio ser. Com que facilidade, então, ele se arrisca a se ferir, tão gravemente que nenhum médico poderia curá-lo. E, além disso, por que seria isto necessário, se tudo carrega consigo o testemunho daquilo que somos, as nossas amizades e os nossos ódios, o nosso olhar e o estreitar da nossa mão, a nossa memória e o nosso esquecimento, os nosso livros e os traços da nossa pena? (Nietzsche, 2004, p. 141)

Obscura, velada, penosa, perigosa e desnecessária é a tarefa do autoconhecimento tal qual a compreende a tradição. Obscura e velada, pois não se encontra jamais o substrato último, o elemento final, no qual se identificaria, de uma vez por todas, a essência humana; penosa e perigosa, pois as descidas às profundezas levam à criação de fantasmas e virtualidades que acabam por tomar forma e se apoderam do corpo; e desnecessária, pois qual a razão para buscar no interior obscuro e velado aquilo que está na nossa frente? Autoconhecimento será, a partir de então, tarefa da águia, não mais da toupeira. A exterioridade como espaço para a tarefa do autoconhecimento cria não apenas uma nova geografia, mas uma nova relação do homem com o espaço, o mundo e o próprio corpo. 0 nome que Nietzsche dará a essa inversão será imanência.

Se a pressão exercida pelo juízo do próximo afasta o homem da busca pelo sentido do seu ser, dada sua covardia, que no texto sobre Schopenhauer é visto como algo negativo, a partir de Humano, demasiado humano, a análise detalhada desse procedimento, porém, em um novo registro, será uma importante aliada na tarefa de crítica da metafísica e da moral, pois será por meio da descoberta da força vinculante da moralidade dos costumes que ele mostrará a ilusão dos valores absolutos como a verdade e o bem.

Se na alteração do espaço de gestação das práticas de autoconhecimento ocorre uma alteração decisiva - afinal, não apenas nosso interior, mas tudo dá testemunho do nosso ser -, Schopenhauer representará para Nietzsche uma transformação fundamental na sua teoria da formação, a saber: a formação da humanidade, do homem, dará lugar gradativamente ao tema da formação de si. Isso não quer dizer 
que Nietzsche se transforme em um mero cultuador do individualismo e do egoísmo, e sim que a tônica das suas reflexões recairá sobre o caso particular. A regra que pode ser extraída dessa transformação parece ser: os experimentos formativos, educativos e morais que queres fazer com os outros, faça-os consigo próprio, em si próprio.

0 que deve ser a educação a partir dessa transformação? Segundo Nietzsche (2004), a educação deve libertar.

Ninguém pode construir no teu lugar a ponte que te seria preciso tu mesmo transpor no fluxo da vida - ninguém, exceto tu. Certamente, existem as veredas e as pontes e os semideuses inumeráveis que se oferecerão para te levar para o outro lado do rio, mas somente na medida em que te vendesses inteiramente: tu te colocarias como penhor e te perderias. Há no mundo um único caminho sobre o qual ninguém, exceto tu, poderia trilhar. (p. 140-141)

Apesar de possuírem muitos pontos em comum, como se revelam agora distintas as concepções de formação e educação presentes nas conferências da Basileia e no texto sobre Schopenhauer, não se pode esquecer a diferença de contexto: enquanto Nietzsche se refere às instituições nas conferências, no texto sobre Schopenhauer, ele se refere ao grande crítico da burocracia institucional. Apesar disso, nem mesmo essa diferença de contexto pode diminuir o abismo entre as duas concepções, e não poderia ser de outra forma. Um texto sobre o tema Schopenhauer como educador deveria eleger a libertação e a autorresponsabilização pelos próprios atos como princípios da educação, o que o texto das conferências da Basileia somente podia aceitar parcialmente. A libertação é um dos requisitos para a formação da personalidade autêntica.

Qual deveria ser a tarefa da educação: descobrir e cultivar o ponto forte de cada um ou relacionar harmonicamente todas as forças entre si? Se desenvolvesse apenas o ponto forte, tornar- se-ia especializada e obtusa para todas as outras dimensões; se, porém, concedesse a mesma importância a cada um dos elementos, criaria um ser superficial. Frente a essas duas tendências da educação alemã do seu tempo, Nietsche (2004) descreve a influência que teria o educador filósofo que ele desejava encontrar.

Este educador filósofo com quem eu sonhava poderia, não se deve duvidar, não somente descobrir a força central, mas também impedir que ela agisse de maneira destrutiva com relação às outras forças; eu imaginava que sua tarefa educativa consistiria principalmente em transformar todo homem num sistema solar e planetário que me revelasse a vida, e em descobrir a lei da sua mecânica superior. (p. 143)

Conjuntamente ao equacionamento das tendências várias e dos pontos fortes de cada ser, o homem educado pelo exemplo de Schopenhauer seria um ser forte, duro, autêntico. Seria também, por essa característica, um homem raro, e sua raridade não decorre apenas da dificuldade em se manter à altura das exigências que ele impõe. Tem a ver, sobretudo, com o fato de que os tipos que emergem do pensamento schopenhaueriano, e dos quais Nietzsche se apossa, são tipos ideais, partes de uma metafísica da natureza e da cultura. Esses tipos são: o filósofo, o artista e o santo.

Além de todas as razões já apresentadas, por qual razão Nietzsche (2004) afirma que Schopenhauer foi "[...] para nós homens profanos, homens seculares no sentido próprio do termo, o primeiro mestre filosófico" (p. 171)? Primeiramente, porque ele é o primeiro filósofo ateu confesso na Alemanha; em segundo lugar, porque ele assume, num mundo sem Deus e sem a providência, o sofrimento voluntário da veracidade; e, por fim, porque ele desenvolve uma teoria que compreende metafisicamente a natureza e a cultura, desde os seres mais ínfimos até os superiores, como uma escada não em direção ao aperfeiçoamento moral, mas como uma escada negativa de privação e negação da vontade. 
Entretanto, no texto sobre Schopenhauer, Nietzsche (2004) não se apropria do aspecto negativo desse pensamento, da parte dessa filosofia que afirma que a vontade é o princípio metafísico do mundo e que, dada sua negatividade plena, sua falta total de objetivo, o mais sensato a fazer seria negá-la. Ele opta por utilizar a teoria do gênio - em que falará sobre o filósofo, o artista e o santo -, pois lhe será possível, então, não apenas falar da negação da vontade, mas também explorar a metafísica da natureza e da cultura. Se Nietzsche focasse sua atenção exclusivamente na teoria schopenhaueriana da vontade, não poderia referir-se ao "novo ciclo de deveres" (p. 175) que devem ser extraídos da teoria do gênio.

Essa teoria afirma que o filósofo, o artista e o santo são os homens verdadeiros, pois são aqueles que transcenderam a animalidade da forma mais soberana possivel e que aparecem como as figuras por meio das quais a natureza se justifica frente a si mesma.

A natureza se quer sempre de utilidade comum, mas ela não pretende encontrar para esse fim os meios e os procedimentos melhores e mais capazes: essa é a sua grande dor e essa é a razão porque ela é melancólica. Que, ao engendrar o filósofo e o artista, ela quisesse tornar a existência inteligivel e significativa para os homens, isto é certo, pois ela aspira a sua própria redenção; mas quanta incerteza, quanta fraqueza e quanta insignificância no efeito que ela alcança, o mais das vezes, com os filósofos e os artistas! Como é raro que ela produza desde então um efeito apenas que fosse! [...] o comportamento da natureza tem toda uma aparência de desperdício, porém, não o desperdício de uma exuberância criminosa, mas o da inexperiência [...]. Ela se comporta com tanta prodigalidade no domínio da cultura quanto nas plantas e sementes [...]. 0 artista e o filósofo testemunham contra o sentido prático da natureza na escolha dos seus meios ainda que estes sejam a mais excelente prova da sabedoria dos seus fins. Eles só afetam poucas pessoas, quando deveriam afetar a todos, e mesmo estas poucas pessoas não são afetadas pela força que o filósofo e o artista deram a seu projétil [...]. A natureza é má economista, suas despesas são bem maiores do que as receitas que ela consegue.

(Nietzsche, 2004, p. 201-202)

Em termos schopenhauerianos, poderse-ia dizer que o filósofo, o artista e o santo são aqueles em que a Vontade já não impera de forma plena. Eles são os que, como já dito anteriormente, vêm em auxílio da physis e corrigem sua loucura e seu desperdício (Nietzsche, 2004). Embora se insinue a negatividade como substrato dessa teoria, o que importa a Nietzsche não é chamar a atenção para a negatividade, mas realçar o aspecto extraordinário desses três tipos, reforçando aquilo que neles é exemplar: a força necessária para sua vitória sobre a natureza, sobre a vontade, que representará não uma negação pura e simples da physis, mas sim uma transfiguração, uma justificação metafísica da natureza, também exemplar para a cultura. Para Schopenhauer, por meio do conhecimento (filósofo), da contemplação estética (artista) e da quietude ascética (santo), é possível chegar à suspensão da banalidade do mundo, das ocupações ordinárias. Já para Nietzsche, desse movimento de suspensão, é possível extrair um aspecto afirmativo e ativo que é a impugnação das modas culturais e educacionais, transformando essa interdição em afirmação. A transformação do sentido da teoria schopenhaueriana possui estreita relação com o movimento por meio do qual Nietzsche recupera, do texto de Schopenhauer, os elementos que lhe permitem construir sua teoria dos tipos formativos e pedagógicos afirmativos. 0 gênio filosófico, o artista e o santo de Nietzsche não possuem a mesma finalidade desses tipos em Schopenhauer. Para aquele, interessa realçar o que há neles de extraordinário, o que neles atesta a força imperiosa de vitória sobre o banal, sobre a moda e a padronização, ou seja, o que neles há de afirmativo. Ao seu juízo nesse período, Schopenhauer foi esse tipo afirmativo. Ele 
era o único que podia libertar ${ }^{4}$ o juízo, liberando o homem da submissão à natureza e à vulgaridade dos modismos, fossem elas quais fossem, inclusive os filosóficos.

\section{Conclusão}

0 que poderíamos esperar de um filósofo quando trata da educação? No caso de Nietzsche, nossas expectativas seriam frustradas caso esperássemos regulamentações para os estabelecimentos de ensino. Tanto mais porque, em Schopenhauer como educador, Nietzsche toma "o caso Schopenhauer" como exemplo revelador da má consciência da cultura alemã - em geral, mas também a filosófica - do seu tempo: o silêncio em torno de Schopenhauer revela a Nietzsche a fraqueza dos alemães em assumir o desafio schopenhaueriano de interpretar e viver a vida a partir do prisma da Vontade, da Pulsão. Portanto, nesse texto, o autor já não se preocupa mais em pensar os estabelecimentos de ensino, tarefa já cumprida nas conferências sobre os estabelecimentos de ensino em 1872.

Como, então, sustentar as reflexões de Nietzsche sobre a educação neste texto para quem se interessa por educação se elas não oferecem respostas práticas pelas quais tanto almejam os interessados, justamente para resolver os problemas dessa área?

$\mathrm{Na}$ Pedagogia, não há prática efetiva sem uma concepção geral sobre a prática que, em última instância, se revela como teoria do agir pedagógico. A teoria pode preceder ou suceder a prática: ora sendo um princípio que se segue e se tenta aplicar ao quotidiano pedagógico, ora sendo um conjunto de princípios aos quais se chega pela análise. Embora não seja indiferente a ordem a que se faz referência - pois ela implicará em consequências políticas e ideológicas -, importa aqui apenas realçar que a teoria sempre está presente, jamais sendo um corpo estranho. Portanto, a teoria, por si só, não é um obstáculo à educação e à pedagogia, e a filosofia, que é carac- terizada como meramente "conceitual", "teórica”, não é necessariamente um inimigo a ser combatido. Se assim for, ainda resta mostrar como, no caso do texto em questão, da teoria se pode passar não à prática, e sim, para utilizar a terminologia nietzschiana, à vivência.

Segundo Nietzsche, a filosofia expressa vivências e, portanto, desde o início, ela é afecção, não havendo mais defesa para a sustentação de uma separação abrupta entre teoria e prática. Nesse particular, Schopenhauer revela a Nietzsche um caso singular: embora tenha produzido uma filosofia com uma terminologia platônica e kantiana, altamente abstrata, ele foi também um dos grandes prosadores da língua alemã. Ele educa, pois cria a consciência para a necessidade do cuidado com a língua, mas o faz a partir da reflexão sobre as vivências humanas, não por meio da análise conceitual. Assim, ensina-nos a ler melhor, a escrever melhor, a pensar melhor, de uma forma simples, genuína. Ele cria a necessidade de topar com o desafio de pensar a particularidade do estilo de cada um, seja na escrita, no pensamento ou na vida, e isso é altamente educativo, ao menos para quem abrigar em si tal desafio.

Nietzsche, à sua maneira, reinstaura um dos modos próprios de ser dos filósofos gregos, que era o de não admitir hiato entre vida e pensamento. Ser educado pela filosofia passou a significar: ser educado para e pela vida. 0 pensamento não é inimigo da vida, é sim uma das suas manifestações. Com isso, ele inova em filosofia, criando uma nova maneira de escrever e pensar, que ele próprio define como "uma arte da suspeita". Suspeitar é educativo já que exige atenção e criatividade.

Entretanto, o que mais se destaca no texto de Nietzsche sobre Schopenhauer, e que

4. A partir de Humano, demasiado humano, o Espírito livre, como figura conceitual ou categoria formativa e pedagógica, exercerá uma explícita crítica ao pessimismo schopenhaueriano, implicando no abandono da filosofia e do homem Schopenhauer. A crítica à metafísica e à moral, marca distintiva do pensamento de Nietzsche a partir de então, implicará na crítica da metafísica schopenhaueriana dos tipos superiores (o filósofo, 0 artista e o santo). 0 Espírito livre zombará do misticismo daquela metafísica da natureza, mostrando a fraqueza daquelas tipologias. 0 banho frio $e$ revigorante já não será mais dado pelo contato com Schopenhauer, mas sim pela proximidade com a ciência, a psicologia e a história. 
por isso figura como argumento conclusivo deste texto, é a exigência constante e imperiosa da autossuperação como uma das máximas fundamentais para a formação do homem. Não estar contente consigo próprio como se é, sem condescender à preguiça ou ao narcisismo modos próprios de ser do homem contemporâ- neo, além de outros, é claro -, parece ser o desafio mais alto que este texto impõe. Mais alto e, por essa razão, mais difícil, interminável. Entretanto, quem tem consciência do que é a vida não se espantará, pois já sabe que a formação e a educação são uma atividade interminável e também intransferível.

\section{Referências bibliográficas}

DIDEROT, J. Réfutations D’Helvetius. Paris: Robert Lafont, 1994.

HELVETIUS. De l'homme (2 vs.). Paris: Fayard, 1989.

HÖLDERLIN, F. Reflexões. Tradução de Márcia de Sá Cavalcante. Rio de Janeiro: Relume-Dumará, 1994.

KANT, I. Resposta a pergunta: 0 que é o esclarecimento? In: A paz perpétua e outros opúsculos. Tradução de Artur Morão. Lisboa: Edições 70, 1995. p. 21-37.

LOCKE, J. Pensamientos sobre la educación. Madrid: Akal, 1986.

MUSIL, Robert. 0 Homem sem qualidades. Tradução de Lya Luft e Carlos Abbenset. Rio de Janeiro: Nova Fronteira, 1989.

NIETZSCHE, F. W. Acerca da verdade e da mentira no sentido extramoral. Tradução de Helga Hoock Quadrado. Lisboa: Relógio D’Água Editores, 1997.

Escritos sobre educação (Sobre o futuro dos nossos estabelecimentos de ensino - III Consideração intempestiva Schopenhauer como educador). Tradução de Noéli Correia de Melo Sobrinho, 2. ed. Rio de Janeiro: PUC-Rio; São Paulo: Loyola, 2004.

Sämtliche werke: kritische studienausgabe (band I). Edição organizada por Giorgio Colli e Mazzino Montinari. München/ Berlin/New York: Deutscher Taschebuch Verlag/Walter de Gruyter, 1988.

SCHOPENHAUER, A. 0 mundo como vontade e representação, tomo I. Tradução de Jair Barboza. São Paulo: Editora da UNESP, 2005.

Sobre a filosofia universitária. Tradução de Maria Lúcia Mello Oliveira Cacciola e Márcio Suzuki, 2. ed. São Paulo: Martins Fontes, 2001.

WEBER, J. F. Formação (Bildung), educação e experimentação: sobre as tipologias pedagógicas em Nietzsche. 2008. Tese (Doutorado) - Universidade Estadual de Campinas, Campinas, 2008.

. Autoridade, singularidade e criação: sobre o problema da formação (Bildung) em 'Sobre o futuro dos nossos estabelecimentos de ensino', de Nietzsche. Educação \& Sociedade. Campinas, v. 29, n. 103, p. 515-532. maio/ago. 2008.

Recebido em 20.05.08

Aprovado em 17.03.09

José Fernandes Weber, doutor pela Faculdade de Educação da UNICAMP, é professor titular (Adjunto A) do Departamento de Filosofia e do curso de Mestrado em Educação da Universidade Estadual de Londrina (UEL). 